Sains Malaysiana 50(3)(2021): 743-751

http://dx.doi.org/10.17576/jsm-2021-5003-16

\title{
A Comparative Study of Microwave-Assisted and Conventional Heating Methods of the Synthesis of 1-(Naphthalene-1-Y1)-3-(O, M, P-Tolyl)Thioureas, DFT Analysis, Antibacterial Evaluation and Drug-Likeness Assessment \\ (Kajian Perbandingan antara Bantuan Mikrogelombang dan Kaedah Pemanasan Konvensional terhadap Sintesis 1-(Naftalena-1-Y1)-3-(O, M, P-Tolil)Tiourea, Analisis DFT, Penilaian Antibakteria dan Kesamaan Ubatan)
}

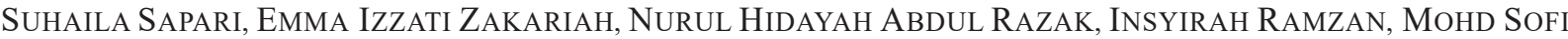 \\ Numin, LeE YoOK Heng, Siti Aishah HasbullaH*
}

\begin{abstract}
New isomers of naphthalene-monothioureas, 3a-3c, were synthesized and characterized by using infrared (IR), ${ }^{1} H$ and ${ }^{13} \mathrm{C}$ nuclear magnetic resonance (NMR) and mass spectroscopies (MS). The compounds were obtained from the reaction of o-, $m$-, $p$ - toluidine with naphthyl isothiocyanate using conventional reflux and microwave-assisted irradiation methods. Microwave-assisted reaction gave higher yields with reduces the reaction time compared to the conventional heating method. Density Functional Theory (DFT) calculations with 6-31G(d,p) basic set at the B3LYP level is carried out to optimize the structure of isomers and calculate the IR, ${ }^{1} \mathrm{H}$ and ${ }^{13} \mathrm{C} N M R$ spectra. The DFT B3LYP calculation of FTIR, ${ }^{1} \mathrm{H}$ and ${ }^{13} \mathrm{C} N M R$ spectra of $\mathbf{3 a - 3 c}$ isomers were in accordance with the experimental data. The calculation of frontier molecular orbitals was also selected to study a relationship as a molecular descriptor in antibacterial activity. The isomers were screened for their in vitro antibacterial activity by using Staphylococcus aureus bacteria. Inhibition activity was displayed for compound $3 \mathrm{c}$ with the value of inhibition zone $7 \pm 0.34 \mathrm{~mm}$ at a concentration of $10 \mu \mathrm{g} / \mathrm{mL}$. All compounds appeared to be in agreement with Lipinski's rule of five assessments as they adhered to most of the rules that can be preliminarily classified as active drug-like.
\end{abstract}

Keywords: Antibacterial activity; DFT; Lipinski’s rule; microwave irradiation; Thiourea isomers

ABSTRAK

Isomer baru monotiourea-naftalena, 3a-3c telah disintesis dan dicirikan dengan menggunakan spektroskopi infra merah (IM), Spektroskopi Resonans Magnetik Nukleus (RMN) ${ }^{1} H$ dan ${ }^{13} \mathrm{C}$ dan Spektrometri jisim (SJ). Sebatian ini diperoleh daripada tindak balas antara o-, m-, p- toluidin dengan naftil isotiosianat menggunakan kaedah konvensional refluks dan penyinaran gelombang mikro. Kaedah penyinaran gelombang mikro memberikan hasil yang lebih tinggi pengurangan masa tindak balas berbanding dengan kaedah refluks. Pengiraan Teori Ketumpatan Berfungsi (DFT) dengan set asas 6-31G $(d, p)$ pada aras B3LYP telah dijalankan untuk mengoptimumkan struktur isomer $3 \boldsymbol{a}-3 \boldsymbol{c}$ dan mengira spektrum IM, ${ }^{1} \mathrm{H}$ dan ${ }^{13} \mathrm{C}$ RMN. Pengiraan B3LYP spektrum IM, ${ }^{1} \mathrm{H}$ dan ${ }^{13} \mathrm{C}$ RMN isomer $3 \mathrm{a}$-3c adalah bertepatan dengan data uji kaji. Pengiraan orbital molekul frontier juga dipilih untuk mengkaji hubung kait struktur sebatian dalam aktiviti antibakteria. Aktiviti antibakteria dijalankan secara in vitro ke atas semua sebatian dengan menggunakan bakteria Staphylococcus aureus. Aktiviti perencatan dapat dilihat pada sebatian 3 c dengan nilai zon perencatan $7 \pm 0.34$ mm pada kepekatan 10 $\mu \mathrm{g} / \mathrm{mL}$. Kesemua sebatian adalah memenuhi penilaian aturan lima Lipinski’s yang boleh dikelaskan berpotensi sebagai ubat aktif.

Kata kunci: DFT; isomer tiourea; mikrogelombang; peraturan Lipinski; sintesis

\section{INTRODUCTION}

Thiourea and its derivatives are relevant compounds in synthetic chemistry (Yin et al. 2008). Thioureas have attracted significant interest in pharmaceutical area and medicinal chemistry, as thioureas exhibit a broad spectrum of biological activities such as antibacterial (Misral et al.
2018), antitumor (Yao et al. 2012), anti-inflammatory (Liu et al. 2012), antidiabetic (Zawawi et al. 2015), and carbonic anhydrase inhibitors (Fakhar et al. 2015). Thioureas also acts as an essential building block in the synthesis of heterocyclic compounds (Kodomari et al. 2005) and as a catalyst in the synthesis of chiral molecules (Gao \& Du 
2013). Moreover, thioureas are known as a versatile reagent that has been extensively studied in coordination chemistry owing to their ability, which capable of coordinating with various types of metals (Fakhar et al. 2016) as well as anion recognition moieties in chemosensors (Khansari et al. 2014). Owing to the usefulness of thiourea compounds in these fields, many approaches have been developed for the synthesis of substituted thioureas including condensation of primary amines with isothiocyanate (Ngah et al. 2018), the reaction of unsubstituted thioureas with primary alkylamines (Yin et al. 2008), the reaction of thiocarbamates with amines (Halimehjani et al. 2009) and condensation of terephthaloyl isothiocyanate with 2-methyl amino ethanol (Fakhar et al. 2015).

In recent decades, microwave-assisted reaction has tremendously applied in the field of organic (Caddick \& Fitzmaurice 2009), inorganic, organometallic, polymer (Bardts et al. 2008) and other applications of chemical reactions. Attributable to the development of commercially available microwave reactors, an enormous number of research papers have been published over the last decades on the application of the microwave irradiation technology in chemical syntheses (Mallakpour \& Zadehnazari 2012). It has been recognized that microwave irradiation technique can be applied to various chemical reactions and offer more advantages than conventional heating methods. The main benefits of microwave-assisted methods are enhancing reaction rates, which reduce reaction times from hours to minutes, improving product yields, and providing efficient energy conversions (Cho et al. 2014). Recently, the one-pot method for the synthesis of substituted thioureas under microwave irradiation has been developed. Based on the concerns of green chemistry, this study attempted to synthesize thiourea isomers of $\mathbf{3 a - 3} \mathbf{c}$ using microwave irradiation and conventional reflux methods to compare the percentage of yield and time of reaction. The potential of the compound as antibacterial agents also evaluated using disc-diffusion technique (DDT) and supported by Lipinski's Rule of Five assessment. The structure of compound obtained was optimized using basic set of DFT / B3-LYP / 6-31G / d, p along with comparison in characterization using FTIR, ${ }^{1} \mathrm{H}$ and ${ }^{13} \mathrm{C} \mathrm{NMR}$.

\section{MATERIALS AND METHODS}

\section{CHEMICALS AND REAGENTS}

The chemicals and reagents were naphthyl isothiocyanate, $o-, m-, p$ - toluidine, dimethyl sulfoxide (DMSO), and dichloromethane were purchased from Across, Sigma Aldrich and Fisher, used without further purification.

\section{INSTRUMENTATIONS}

All reactions were performed under microwave irradiation method using Anton Paar Monowave 400. Fourier transform-infrared spectroscopy (FTIR) spectra were recorded on the Perkin-Elmer in the range 400$4000 \mathrm{~cm}^{-1}$ using the $\mathrm{KBr}$ pellet method. NMR $\left({ }^{1} \mathrm{H}\right.$ dan ${ }^{13} \mathrm{C}$ ) spectra were recorded on a Bruker FT-NMR 600 MHz and Joel EX90 FT NMR $400 \mathrm{MHz}$ using deuterated dimethyl sulfoxide (DMSO- $d_{6}$ ) as a solvent. Mass spectra were recorded on a Bruker micro TOF-Q spectrometer by ESI-MSI in the positive ion mode. The compounds were isolated by thin-layer chromatography (TLC) techniques using Merck DC Kieselgel 60 F254 silica gel.

SYNTHESIS OF THIOUREA 1-(NAPHTHALENE-1-YL)3-( $O$ TOLYL)THIOUREA(3a), 1-(NAPHTHALENE-1-YL)-3-(M-TOLYL) THIOUREA(3b) AND 1-(NAPHTHALENE-1-YL)3-(P-TOLYL) THIOUREA(3c) USING REFLUX METHOD

Compound $\mathbf{3 a}$ was synthesized by reacting one equivalent of o-toluidine $\mathbf{2 a}(0.21 \mathrm{~g}, 2.0 \mathrm{mmol})$ with one equivalent of naphthyl isothiocyanate $1(0.37 \mathrm{~g}, 2.0$ $\mathrm{mmol}$ ) in dichloromethane under reflux condition. TLC analysis was carried out to confirm the formation of the products qualitatively. The precipitate was formed after 6-hours reaction and was filtered out as white solid. The above procedure was repeated by using $\mathrm{m}$-toluidine $\mathbf{2} \mathbf{b}$ and p-toluidine $\mathbf{2 c}$.

(3a) White solid; Mp: $190.65-195.75^{\circ} \mathrm{C}$; IR (KBr, $\left.\mathrm{cm}^{-1}\right)$; 3377, 1492, 1261; ${ }^{1} \mathrm{H}$ NMR (400 MHz, $d_{6}$-DMSO) $\delta 2.27\left(3 \mathrm{H}, s, \mathrm{CH}_{3}\right), 7.15-7.16\left(1 \mathrm{H}, d, \mathrm{Ar}_{-} \mathrm{H}_{\mathrm{d}}, J=1.6 \mathrm{~Hz}\right)$, 7.17-7.18 $\left(1 \mathrm{H}, d, \mathrm{Ar}_{-} \mathrm{H}_{\mathrm{b}} J=2.0 \mathrm{~Hz}\right), 7.18-7.20(1 \mathrm{H}, d$, $\left.\mathrm{Ar}^{-} \mathrm{H}_{\mathrm{k}}, J=2.0 \mathrm{~Hz}\right), 7.22-7.23\left(1 \mathrm{H}, s, \mathrm{Ar}-\mathrm{H}_{\mathrm{a}} J=2.0 \mathrm{~Hz}\right)$, 7.27- 7.29 (1H, $\left.m, \mathrm{Ar}_{-} \mathrm{H}_{\mathrm{c}}\right), 7.53-7.54\left(1 \mathrm{H}, m, \mathrm{Ar}-\mathrm{H}_{\mathrm{j}}\right), 7.54-$ $7.55\left(1 \mathrm{H}, m, \mathrm{Ar}_{-} \mathrm{H}_{\mathrm{i}}\right), 7.55-7.57\left(1 \mathrm{H}, m, \mathrm{Ar}-\mathrm{H}_{\mathrm{g}}\right), 7.57-7.58$ $\left(1 \mathrm{H}, m, \mathrm{Ar}_{-} \mathrm{H}_{\mathrm{f}}\right), 7.59-7.88\left(1 \mathrm{H}, m, \mathrm{Ar}-\mathrm{H}_{\mathrm{h}}\right), 7.96-8.011(1 \mathrm{H}$, $m$, Ar- $\left.\mathrm{H}_{\mathrm{e}}\right), 9.23(1 \mathrm{H}, s, \mathrm{NH}), 9.77(1 \mathrm{H}, s, \mathrm{NH}) ;{ }^{13} \mathrm{C} \mathrm{NMR}$ (150 MHz, $d_{6}$-DMSO) $\delta 18.4\left(\mathrm{CH}_{3}\right), 123.6-130.7(11 \times$ $\mathrm{ArCH}), 134.4-138.5$ (5 × ArC), $182.4(\mathrm{C}=\mathrm{S}) ; \mathrm{MS}(\mathrm{ESI})$ $\mathrm{m} / \mathrm{z}$ : calculated for $\mathrm{C}_{18} \mathrm{H}_{16} \mathrm{~N}_{2} \mathrm{~S}$ (292.09), found $\left({\left.\mathrm{M}-\mathrm{Na}^{+}\right)}^{+}\right.$ (315.0667).

(3b) White solid; Mp: 163.95-164.45 ${ }^{\circ} \mathrm{C}$; IR $\left(\mathrm{KBr}, \mathrm{cm}^{-1}\right) 3170,1530,1205 ;{ }^{1} \mathrm{H} \mathrm{NMR}\left(600 \mathrm{MHz}, d_{6}-\right.$ DMSO) $\delta 2.29\left(3 \mathrm{H}, s, \mathrm{CH}_{3}\right), 6.94-6.96\left(1 \mathrm{H}, d, \mathrm{Ar}-\mathrm{H}_{\mathrm{a}}, J=\right.$ 11.4 Hz), 7.19-7.22 (1H, $\left.d, \mathrm{Ar}_{-} \mathrm{H}_{\mathrm{d}}, J=13.2 \mathrm{~Hz}\right), 7.23-7.32$ $\left(1 \mathrm{H}, m, \mathrm{Ar}-\mathrm{H}_{\mathrm{b}}\right), 7.52-7.53\left(1 \mathrm{H}, m, \mathrm{Ar}-\mathrm{H}_{\mathrm{k}}\right), 7.54-7.56(1 \mathrm{H}$, $m$, Ar- $\left.\mathrm{H}_{\mathrm{c}}\right), 7.60-7.86\left(1 \mathrm{H}, m, \mathrm{Ar}-\mathrm{H}_{\mathrm{j}}\right), 7.86-7.87(1 \mathrm{H}, m, \mathrm{Ar}-$ $\left.\mathrm{H}_{\mathrm{i}}\right), 7.86-7.97\left(1 \mathrm{H}, m\right.$, Ar- $\left.\mathrm{H}_{\mathrm{g}}\right), 7.97-7.98\left(1 \mathrm{H}, m\right.$, Ar- $\left.\mathrm{H}_{\mathrm{h}}\right)$, 7.98-7.99 (1H, $m$, Ar- $\left.\mathrm{H}_{\mathrm{e}}\right), 9.71(1 \mathrm{H}, s, \mathrm{NH}), 9.82(1 \mathrm{H}, s$, $\mathrm{NH}) ;{ }^{13} \mathrm{C}$ NMR $\left(300 \mathrm{MHz}, d_{6}\right.$-DMSO) $\delta 21.5\left(\mathrm{CH}_{3}\right), 121.7-$ $130.4(11 \times \mathrm{ArCH}), 134.4-139.9(5 \times \mathrm{ArC}), 181.7(\mathrm{C}=\mathrm{S})$; MS (ESI) m/z: calculated for $\mathrm{C}_{18} \mathrm{H}_{16} \mathrm{~N}_{2} \mathrm{~S}$ (292.09), found $\left(\mathrm{M}-\mathrm{Na}^{+}\right)$(315.0667). 
(3c) White solid; Mp: 163.95-164.45 ${ }^{\circ} \mathrm{C}$; IM $\left(\mathrm{KBr}, \mathrm{cm}^{-1}\right) 3209,1494,1216$; ${ }^{1} \mathrm{H}$ NMR $\left(400 \mathrm{MHz}, d_{6}-\right.$ DMSO) $\delta 2.28\left(3 \mathrm{H}, s, \mathrm{CH}_{3}\right), 7.13-7.37\left(1 \mathrm{H}, m, \mathrm{Ar}-\mathrm{H}_{\mathrm{a}}\right.$ ), 7.39-7.52 (1H, $m$, Ar- $\left.\mathrm{H}_{\mathrm{k}}\right), 7.53-7.57\left(1 \mathrm{H}, m, \mathrm{Ar}-\mathrm{H}_{\mathrm{a}, \mathrm{d}}\right)$, 7.58-7.59 (1H, $m$, Ar- $\left.\mathrm{H}_{\mathrm{j}}\right), 7.84-7.86\left(1 \mathrm{H}, s, \mathrm{Ar}-\mathrm{H}_{\mathrm{i}}\right), 7.87-$ $7.96\left(1 \mathrm{H}, m, \mathrm{Ar}_{\mathrm{H}}\right), 7.96-7.97\left(1 \mathrm{H}, m, \mathrm{Ar}-\mathrm{H}_{\mathrm{f}}\right), 7.97-7.98$ $\left(1 \mathrm{H}, m, \mathrm{Ar}_{-} \mathrm{H}_{\mathrm{h}}\right), 7.90-7.93\left(1 \mathrm{H}, m, \mathrm{Ar}-\mathrm{H}_{\mathrm{e}}\right), 9.78(1 \mathrm{H}, s, \mathrm{NH})$, $9.66(1 \mathrm{H}, s, \mathrm{NH}) ;{ }^{13} \mathrm{C}$ NMR $(150 \mathrm{MHz}, d$-DMSO) $\delta 21.0$ $\left(\mathrm{CH}_{3}\right), 123.6-130.5(11 \times \mathrm{ArCH}), 134.3-137.4(5 \times \mathrm{ArC})$, $181.8(\mathrm{C}=\mathrm{S})$; MS (ESI) $\mathrm{m} / \mathrm{z}$ : calculated for $\mathrm{C}_{18} \mathrm{H}_{16} \mathrm{~N}_{2} \mathrm{~S}$ (292.09), found $\left(\mathrm{M}-\mathrm{Na}^{+}\right)(315.0667)$

SYNTHESIS OF 1-(NAPHTHALENE-1-YL)3-(O-TOLYL) THIOUREA(3A), 1-(NAPHTHALENE-1-YL)-3-( $M$-TOLYL) THIOUREA(3B) AND 1-(NAPHTHALENE-1-YL)3-(P-TOLYL) THIOUREA(3C) USING MICROWAVE IRRADIATION METHOD

A mixture of $o$-toluidine $2 \mathrm{a}(0.21 \mathrm{~g}, 2.0 \mathrm{mmol})$ and naphthyl isothiocyanate $\mathbf{1}(0.37 \mathrm{~g}, 2.0 \mathrm{mmol})$ were dissolved in dichloromethane. The mixture was then irradiated in the microwave synthesizer at $360 \mathrm{~W}$ for 5 min and formed a white precipitate. The white precipitate was analyzed using TLC to confirm the formation of the product. The above procedure was repeated to synthesize compound $\mathbf{3 b}$ and $\mathbf{3 c}$ by substituting compound $\mathbf{2 a}$ with $m$-toluidine (2b) and $p$-toluidine (2c).

(3a) White solid; Mp: $190.35-196.35{ }^{\circ} \mathrm{C}$; IR (KBr, $\left.\mathrm{cm}^{-1}\right) 3263,1623,1248 ;{ }^{1} \mathrm{H}$ NMR (400 MHz, $d_{6}$-DMSO) $\delta 2.49\left(3 \mathrm{H}, s, \mathrm{CH}_{3}\right), 6.95-6.96\left(1 \mathrm{H}, d, \mathrm{Ar}-\mathrm{H}_{\mathrm{d}} J=7.2 \mathrm{~Hz}\right)$, 7.19-7.22 (1H, $\left.d, \mathrm{Ar}-\mathrm{H}_{\mathrm{b}}\right), 7.22-7.23\left(1 \mathrm{H}, m, \mathrm{Ar}-\mathrm{H}_{\mathrm{k}}\right), 7.31-$ $7.52\left(1 \mathrm{H}, m, \mathrm{Ar}-\mathrm{H}_{\mathrm{o}}\right), 7.52-7.53\left(1 \mathrm{H}, m, \mathrm{Ar}-\mathrm{H}_{\mathrm{c}}\right), 7.54-7.56$ $\left(1 \mathrm{H}, m, \operatorname{Ar}-\mathrm{H}_{\mathrm{i}}\right), 7.57-7.59\left(1 \mathrm{H}, m, \mathrm{Ar}-\mathrm{H}_{\mathrm{i}}\right), 7.60-7.61(1 \mathrm{H}, m$, $\left.\mathrm{Ar}-\mathrm{H}_{\mathrm{g}}\right), 7.85-7.87\left(1 \mathrm{H}, m, \mathrm{Ar}-\mathrm{H}_{\mathrm{f}}\right), 7.96-7.97\left(1 \mathrm{H}, m, \mathrm{Ar}-\mathrm{H}_{\mathrm{h}}\right)$, 7.98-7.99 (1H, m, Ar-H $), 9.87(1 \mathrm{H}, s, \mathrm{NH}), 9.73(1 \mathrm{H}, s$, $\mathrm{NH}) ;{ }^{13} \mathrm{C}$ NMR $\left(150 \mathrm{MHz}, d_{6}\right.$-DMSO) $\delta 21.5\left(\mathrm{CH}_{3}\right), 121.7-$ $130.5(11 \times \mathrm{ArCH}), 134.4-139.9(5 \times \mathrm{ArC}), 181.7(\mathrm{C}=\mathrm{S})$.

(3b) White solid; Mp: 163.35-165.35 ${ }^{\circ} \mathrm{C}$; IR $\left(\mathrm{KBr}, \mathrm{cm}^{-1}\right) 3177,1537,1205 ;{ }^{1} \mathrm{H}$ NMR $\left(400 \mathrm{MHz}, d_{6}-\right.$ DMSO) $\delta 2.29\left(3 \mathrm{H}, s, \mathrm{CH}_{3}\right), 7.13-7.15\left(1 \mathrm{H}, d, \mathrm{Ar}_{-} \mathrm{H}_{\mathrm{a}}, \mathrm{d}, J\right.$ $=7.2 \mathrm{~Hz}), 7.37-7.39\left(1 \mathrm{H}, d, \mathrm{Ar}-\mathrm{H}_{\mathrm{b}}, J=8.4 \mathrm{~Hz}\right), 7.52-7.53$ $\left(1 \mathrm{H}, m, \mathrm{Ar}-\mathrm{H}_{\mathrm{k}}\right), 7.54-7.56\left(1 \mathrm{H}, m, \mathrm{Ar}-\mathrm{H}_{\mathrm{c}}\right), 7.56-7.58(1 \mathrm{H}, m$, Ar- $\left.\mathrm{H}_{\mathrm{j}}\right), 7.60-7.61\left(1 \mathrm{H}, m, \mathrm{Ar}-\mathrm{H}_{\mathrm{i}}\right), 7.85-7.87\left(1 \mathrm{H}, m, \mathrm{Ar}-\mathrm{H}_{\mathrm{g}}\right)$, 7.96-7.97 (1H, $m$, Ar- $\left.\mathrm{H}_{\mathrm{f}}\right), 7.97-7.98\left(1 \mathrm{H}, m, \mathrm{Ar}-\mathrm{H}_{\mathrm{h}}\right), 7.98-$ $7.99\left(1 \mathrm{H}, m, \mathrm{Ar}-\mathrm{H}_{\mathrm{e}}\right), 9.80(1 \mathrm{H}, s, \mathrm{NH}), 9.68(1 \mathrm{H}, s, \mathrm{NH}) ;{ }^{13} \mathrm{C}$ NMR $\left(150 \mathrm{MHz}, d\right.$-DMSO) $\delta 21.0\left(\mathrm{CH}_{3}\right), 123.6-130.5(12$ $\times \mathrm{ArCH}), 134.3-137.4(4 \times \mathrm{ArC}), 181.8(\mathrm{C}=\mathrm{S})$.

(3c) White solid; Mp: $185.35-190.35{ }^{\circ} \mathrm{C}$; IM (KBr, $\mathrm{cm}^{-1}$ ) 3207, 1489, 1220; ${ }^{1} \mathrm{H}$ NMR (400 MHz, $d_{6}$-DMSO) $\delta 2.27\left(3 \mathrm{H}, s, \mathrm{CH}_{3}\right), 7.14-7.15\left(1 \mathrm{H}, d, \mathrm{Ar}_{-} \mathrm{H}_{\mathrm{a}, \mathrm{d}}, J=6.4 \mathrm{~Hz}\right)$,

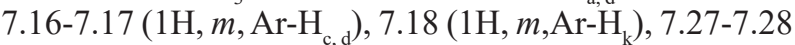
$\left(1 \mathrm{H}, m, \mathrm{Ar}-\mathrm{H}_{\mathrm{j}}\right), 7.28-7.29\left(1 \mathrm{H}, m, \mathrm{Ar}-\mathrm{H}_{\mathrm{i}}\right), 7.84-7.86(1 \mathrm{H}, m$, Ar- $\left.\mathrm{H}_{\mathrm{g}}\right), 7.94-7.96\left(1 \mathrm{H}, m, \mathrm{Ar}-\mathrm{H}_{\mathrm{f}}\right), 7.99-8.01\left(1 \mathrm{H}, m, \mathrm{Ar}-\mathrm{H}_{\mathrm{g}}\right)$, $8.06-8.20(1 \mathrm{H}, m$, Ar-He), 9.68(1H, $s, \mathrm{NH}), 9.81\left(1 \mathrm{H}^{\mathrm{g}}, s\right.$, $\mathrm{NH}) ;{ }^{13} \mathrm{C} \mathrm{NMR}\left(150 \mathrm{MHz}, d_{6}\right.$-DMSO) $\delta 18.3\left(\mathrm{CH}_{3}\right), 123.5-$ $130.6(10 \times \mathrm{ArCH}), 134.4-138.4(4 \times \mathrm{ArC}), 182.4(\mathrm{C}=\mathrm{S})$.
ANTIBACTERIAL STUDIES OF 3a, 3b, AND 3c

Antibacterial study was carried out using a disc diffusion technique towards Staphylococcus aureus. The positive control was Streptomycin $(10 \mu \mathrm{L} / \mathrm{mL})$ compound and DMSO (100\% of concentration) was used as a negative control. The stock solutions of compounds $\mathbf{3} \mathbf{a}-\mathbf{3} \mathbf{b}$ were prepared at a concentration of $10 \mu \mathrm{g} / \mathrm{mL}$ and sampled per-sampled disc. Then, the agar plate was spread with target bacteria and incubated at $37^{\circ} \mathrm{C}$ for $24 \mathrm{~h}$. After 24 $\mathrm{h}$, the diameter of the non-bacterial area was measured to compare antibacterial activity levels with a positive control level.

\section{COMPUTATIONAL STUDIES}

The DFT optimization calculations of $\mathbf{3 a - 3} \mathbf{c}$ were performed by using Gaussian 16 and visualized by Gaussview 9 software [DFT/B3-LYP with the basis set of $6-31 G(d, p)]$ at the Centre of Information and Communication Technology, Universiti Teknologi Malaysia. The theoretical analysis of FTIR, ${ }^{1} \mathrm{H}$ NMR, and ${ }^{13} \mathrm{C}$ NMR obtained from computational studies were correlated with the experimental data of compounds 3a-3c. The calculation of frontier molecular orbitals of the 'Highest Occupied Molecular Orbital' (HOMO) and 'Lower Unoccupied Molecular Orbital' (LUMO) were performed to explore the potential of the ${ }^{\circ} \mathrm{n}$ antibacterial agent.

\section{RESULTS AND DISCUSSION}

\section{SYNTHESIS OF MONO- THIOUREA DERIVATIVES USING REFLUX AND MICROWAVE IRRADIATION}

Three derivatives of mono-thiourea were synthesized using a reflux and microwave irradiation technique giving a percentage yield as tabulated in Table 1 . The utilization of the microwave irradiation resulted in a noticeable acceleration in the reaction rate, which can be observed from the reduction in the reaction times, from 6 $\mathrm{h}$ (reflux method) to $5 \mathrm{~min}$ (microwave irradiation).

The results also showed the visible improvement in the percentage yields of the products when using microwave irradiation (82-89\%) compared to the reflux method (31-82\%). The improvement in the percentage yields and enhancement in the reaction time using a microwave irradiation method is attributed to the continuous high heating efficiency and adequate temperature control system (Sheryn et al. 2018). In the microwave system, microwave energy promoting a uniform and direct heating of the starting materials, which surges the reaction to take place rapidly and optimally. The use of a slightly polar dichloromethane solvent also helps in the optimum energy absorption of the microwave methods (Larhed \& Hallberg 2001). In contrast, the 
conventional heating method of reflux necessitates reflux heating equipment such as silicon oil and heater, which require external heat sources. This method usually requires longer heating time with the use of high temperatures, which led to overheating on the solvent surface and consequently resulted in decomposition of the solvent and starting material. In this sense, it may become the factor for the low productivity of the product $\mathbf{3 b}(31 \%)$ obtained by the reflux method. Besides, the formation of by-products is high for the reflux method because it requires a longer time for the reaction to be completed (Gangrade et al. 2015; Ravichandran \& Karthikeyan 2011).<smiles>S=[N+]c1cccc2ccccc12</smiles>

1<smiles>[R]c1ccc(N)cc1</smiles>

$2 a, 2 b$, and $2 c$
$\mathrm{CH}_{2} \mathrm{Cl}_{2}$ (Dichloromethane) Reflux $(6 \mathrm{~h})$ or MW (5 min)

\footnotetext{
2a and $3 a=R=o-C_{3}$

$2 b$ and $3 b=R=m-C_{3}$

$2 \mathrm{c}$ and $3 \mathrm{c}=\mathrm{R}=p-\mathrm{CH}_{3}$
}

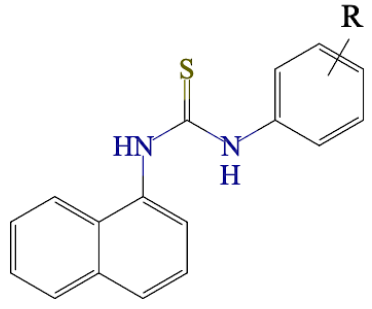

$3 a, 3 b$, and $3 c$

FIGURE 1. The reaction scheme of the synthesis of thiourea derivatives 3a-3c

TABLE 1. Percentage yield and reaction time for reflux and microwave methods

\begin{tabular}{ccccc}
\hline \multirow{2}{*}{ Compound } & \multicolumn{3}{c}{ Reflux } & \multicolumn{3}{c}{ Microwave } \\
\cline { 2 - 5 } & Yield (\%) & Time (min) & Yield (\%) & Time (min) \\
\hline $3 \mathrm{a}$ & 72 & 360 & 87 & 5 \\
$3 \mathrm{~b}$ & 31 & 360 & 82 & 5 \\
$3 \mathrm{c}$ & 82 & 360 & 89 & 5 \\
\hline
\end{tabular}

\section{STRUCTURE OPTIMIZATION}

The molecular geometry of the 3a-3c were optimized using a DFT method with 6-31 G(d,p) basic set giving the optimum energy value (a.u), dipole moment, and time for normal termination. The more negative energy-optimized, the more stable geometry for the compound, as shown in Table 2, 3b $>$ 3a $>$ 3c (Marcos et al. 2013). Theoretical DFT calculation for the bond length for compound $\mathbf{3 a}$, $\mathbf{3 b}, \mathbf{3 c}$ was summarized in Table 3 and strongly agree with previous study (Sapari et al. 2018).

TABLE 2. Optimized value of DFT calculation for mono-thiourea derivatives

\begin{tabular}{lccc}
\hline \multicolumn{1}{c}{ Optimized value } & $\mathbf{3 a}$ & $\mathbf{3 b}$ & $\mathbf{3 c}$ \\
\hline Energy (a.u) & -1203.298668 & -1203.298875 & -1203.298652 \\
Dipole moment & 5.765936 & 5.353422 & 5.537410 \\
Time & $241 \mathrm{~min} 17 \mathrm{~s}$ & 197 min $52 \mathrm{~s}$ & 170 min $35 \mathrm{~s}$ \\
\hline
\end{tabular}


TABLE 3. Bond length $(\AA)$ optimized from DFT calculation

\begin{tabular}{|c|c|c|c|}
\hline Bond & 3a & $3 b$ & $3 c$ \\
\hline $\mathrm{C}=\mathrm{S}$ & 1.68167 & 1.67689 & 1.67707 \\
\hline N-H(methoxy) & 1.01302 & 1.01069 & 1.01065 \\
\hline N-H(naphthyl) & 1.01055 & 1.01334 & 1.01328 \\
\hline $\mathrm{C}-\mathrm{CH}_{3}$ & 1.50607 & 1.51072 & 1.50977 \\
\hline C-N & 1.37452 & 1.37693 & 1.37643 \\
\hline
\end{tabular}

COMPARISON FTIR DATA WITH COMPUTATIONAL DFT

The resemblance of infrared spectroscopy for reflux and microwave fulfilled with the DFT computations have been used as convincing tools in the vibrational analysis of the thiourea compound. From the calculation, the observed bands give the most precise value compared to the previous theoretical and experimental data. The experimental and theoretical FTIR spectra of the title compound show several functional groups corresponding to their structural positions. The characteristics of vibrational frequencies for the three main functional groups are easily obtained and tabulated in Table 4 and appear at the range as in the previous study (Ying et al. 2019). The peak appears in the spectrum for compound synthesized by reflux method has less than $10 \%$ percentage deviation compared to microwave and DFT computation spectrum, indicating that both methods are reliable and acceptable in synthesizing and optimizing the compound. From the average percentage deviation that calculated using equation (1), the percentage deviation for thioamide $(\mathrm{N}-\mathrm{H}-\mathrm{C}=\mathrm{S})$ stretching showed by compound $\mathbf{3 b}$ is $4.18 \%$ for microwave method and $6.47 \%$ for DFT calculation, compared to the reflux method which is the established method for synthesizing thiourea compound (Misral et al. 2018).

Percentage deviation $=\frac{\text { Calcualted value }- \text { Experimental value }}{\text { Experimental value }} \times 100 \%$

TABLE 4. Comparison data FTIR for experimental, microwave method and computational calculation

\begin{tabular}{|c|c|c|c|c|}
\hline Compound & Functional group & $\begin{array}{c}\text { Experimental } \\
\text { (reflux) }\end{array}$ & $\begin{array}{l}\text { Experimental } \\
\text { (microwave) }\end{array}$ & $\begin{array}{c}\text { Computational } \\
\text { (DFT) }\end{array}$ \\
\hline \multirow[t]{3}{*}{$3 a$} & $\mathrm{~N}-\mathrm{H}-\mathrm{C}=\mathrm{S}$ & 3287.5 & 3335.9 & 3624.3 \\
\hline & $\mathrm{N}-\mathrm{H}-\mathrm{ArOCH}_{3}$ & 3203.6 & 3343.7 & 3573.3 \\
\hline & $\mathrm{C}=\mathrm{S}$ & 1533.7 & 1632.6 & 1221.4 \\
\hline \multirow[t]{3}{*}{$3 b$} & $\mathrm{~N}-\mathrm{H}-\mathrm{C}=\mathrm{S}$ & 3343.4 & 3203.6 & 3559.4 \\
\hline & $\mathrm{N}-\mathrm{H}-\mathrm{ArOCH}_{3}$ & 3255.5 & 3285.6 & 3623.5 \\
\hline & $\mathrm{C}=\mathrm{S}$ & 1498.3 & 1537.5 & 1221.4 \\
\hline \multirow[t]{3}{*}{$3 \mathrm{c}$} & $\mathrm{N}-\mathrm{H}-\mathrm{C}=\mathrm{S}$ & 3216.6 & 3207.8 & 3568.9 \\
\hline & $\mathrm{N}-\mathrm{H}-\mathrm{ArOCH}_{3}$ & 3209.3 & 3224.1 & 3625.1 \\
\hline & $\mathrm{C}=\mathrm{S}$ & 1498.3 & 1498.3 & 1217.4 \\
\hline
\end{tabular}


COMPARISON ${ }^{1} \mathrm{H}$ AND ${ }^{13} \mathrm{C}$ NMR EXPERIMENTAL DATA WITH DFT CALCULATION

The ${ }^{1} \mathrm{H}$ NMR spectra (reflux and microwave) of the synthesized compound in DMSO- $d_{6}$ are consistent with the structural formula. The overall data for the reflux and microwave method were in good agreement. ${ }^{1} \mathrm{H}$ NMR spectrum for all the derivatives shows the two-singlet peak at deshielded range corresponding to the signal of the thioamide $(\mathrm{N}-\mathrm{H}-\mathrm{C}=\mathrm{S})$ and $\left(\mathrm{N}-\mathrm{H}-\mathrm{ArOCH}_{3}\right)$ amide functional group. The lower percentage deviation in the reflux and microwave method for the peak of thioamide $(1.02,2.03,3.06)$ and amide $(5.04,3.08,2.27)$ shows that both methods are suitable and reliable in synthesizing the compound. The theoretical chemical shift of ${ }^{1} \mathrm{H}$ NMR using a hybrid method of SCF-GIAO-DFT/B3LYP 6-31G(d, p) showed huge percentage deviation of 19.14, 13.85, 20.86 for thioamide and 24.13, 16.58, 20.08 for amide functional group compared to the reflux method (Table 5), which were attributed to the effect of the solvation parameter during calculation in the gas phase (Zhu et al. 2012). Similarly, from the ${ }^{13} \mathrm{C}$ NMR spectra, the thioamide group appears at the range of 181.7 to $182.4 \mathrm{ppm}$ with a small percentage deviation for reflux and microwave method $(3.8,0.05$, 3.35 ) and this shows that both approaches are promising (Table 6). As for the calculation of DFT, the significant percentage deviations $(15.35,16.51,25.9)$ obtained is due to the influence of the solvent parameter used in the gas phase. In general, all the characterization for the synthesized compounds using experimental and microwave methods confirmed the formation of compounds $\mathbf{3 a - 3} \mathbf{c}$.

TABLE 5. Experimental (reflux and microwave) and computational data for ${ }^{1} \mathrm{H}$ NMR spectrum

\begin{tabular}{ccccc}
\hline Compound & Functional group & $\begin{array}{c}\text { Experimental } \\
\text { (reflux) }\end{array}$ & $\begin{array}{c}\text { Experimental } \\
\text { (microwave) }\end{array}$ & $\begin{array}{c}\text { Computational } \\
\text { DFT }\end{array}$ \\
\hline $3 \mathrm{a}-\mathrm{H}-\mathrm{C}=\mathrm{S}$ & 9.77 & 9.87 & 7.90 \\
$\mathrm{~N}-\mathrm{H}-\mathrm{ArOCH}_{3}$ & & 9.73 & 8.86 \\
$\mathrm{~N}-\mathrm{H}-\mathrm{C}=\mathrm{S}$ & 9.23 & 9.80 & 8.10 \\
$\mathrm{~N}-\mathrm{H}-\mathrm{ArOCH}_{3}$ & 9.82 & 9.68 & 7.74 \\
$\mathrm{~N}-\mathrm{H}-\mathrm{C}=\mathrm{S}$ & 9.71 & 9.81 & 7.71 \\
\hline
\end{tabular}

TABLE 6. Experimental (reflux and microwave) and computational data for ${ }^{13} \mathrm{C}$ NMR spectrum

\begin{tabular}{ccccc}
\hline Compound & Functional group & $\begin{array}{r}\text { Experimental } \\
\text { (reflux) }\end{array}$ & $\begin{array}{c}\text { Experimental } \\
\text { (microwave) }\end{array}$ & $\begin{array}{c}\text { Computational } \\
\text { DFT }\end{array}$ \\
\hline 3a & $\mathrm{C}=\mathrm{S}$ & 182.4 & 181.7 & 185.2 \\
$\mathbf{3 b}$ & $\mathrm{C}=\mathrm{S}$ & 181.7 & 181.8 & 184.7 \\
$\mathbf{3 c}$ & $\mathrm{C}=\mathrm{S}$ & 181.8 & 182.4 & 186.5 \\
\hline
\end{tabular}


In the present study, antibacterial activity evaluation was performed for 3a-3c against Staphylococcus aureus bacteria. Antibacterial activity was recorded using compound $3 \mathbf{c}$ with a zone of inhibition (ZOI) was $7 \pm$ $0.34 \mathrm{~mm}$ and compound $\mathbf{3 a}$ and $\mathbf{3 b}$ did not show any antibacterial activity (Table 7). The biological property of compound $\mathbf{3 c}$ is due to the para-position of a methyl group which induced the effect of conjugation and induction (Yanai et al. 2004; Yin et al. 2012). The value of the HOMO, LUMO, and HOMO-LUMO energy gap generated from the DFT calculation is an established parameter to correlate with the antibacterial potential of the synthesized compound (Figure 2). The smallest HOMO-LUMO energy gap (E gap) is referred to a compound having more zone of inhibition (ZOI) activity compared to another compound with same derivatives (Table 8) (Farzanfar et al. 2015; Yang et al. 2012). In this study, compound $\mathbf{3 c}$ gave the lowest value of energy gap ( $3.9837 \mathrm{eV})$ compared to compound 3a $(4.0736 \mathrm{eV})$ and $\mathbf{3 b}(4.0572 \mathrm{eV})$ which provide an ideal environment for inhibition towards the bacteria Staphylococcus aureus, $3 \mathbf{c}$ with ZOI value of $7.0 \pm 0.56 \mathrm{~mm}$ compared to the ZOI of positive control (Streptomysin) 16 $\pm 0.56 \mathrm{~mm}$ (Table 7). Drug-likeness assessment analysis was performed using Lipinski's rule of five and showed that all three derivatives $\mathbf{3 a - 3} \mathbf{c}$ fulfilled the parameter as potential drugs (Table 9). The molecular weights were smaller than $500 \mathrm{~g} / \mathrm{mol}$, and the lipophilicity properties $(\log \mathrm{P})$ were less than 5 , which demonstrated that the compounds are easily absorbed into the cell wall of bacteria for inhibition activity (Ardila et al. 2017).

TABLE 7. Inhibition zone (mm) antibacterial activity for thiourea derivatives 3a-3c and control positive Streptomysin $10 \mu \mathrm{g} /$ $\mathrm{mL})$

Staphylococcus aureus (mm)

\author{
Streptomysin $(10 \mu \mathrm{g} / \mathrm{mL})-$ Control positive \\ 1-(napthalene-1-yl)-3-( 0- tolyl)thiourea, 3a \\ 1-(napthalene-1-yl)-3-( $m$ - tolyl)thiourea, 3b \\ 1-(napthalene-1-yl)-3-( $p$ - tolyl)thiourea, 3c
}

$16 \pm 0.56$

$7 \pm 0.34$

TABLE 8. Value of HOMO, LUMO, and energy gap (HOMO-LUMO)

\begin{tabular}{lccc}
\hline Compound & HOMO $(\mathrm{eV})$ & LUMO $(\mathrm{eV})$ & HOMO-LUMO $(\Delta \mathrm{E} / \mathrm{eV})$ \\
\hline $3 \mathrm{a}$ & 1.3986 & 5.4722 & 4.0736 \\
$3 \mathrm{~b}$ & 1.3823 & 5.4395 & 4.0572 \\
$3 \mathrm{c}$ & 1.4803 & 5.4640 & 3.9837 \\
\hline
\end{tabular}

TABLE 9. Lipinski's rule of five calculated for compound 3a-3c

\begin{tabular}{lccc}
\hline Lipinski rule/compounds & 3a & 3b & 3c \\
\hline 1. Log P (lipophilicity) $<5$ & 3.283 & 3.843 & 3.843 \\
2. Hydrogen bond donor $<5$ & 2 & 2 & 2 \\
3. Hydrogen bond acceptor $<5$ & 2 & 2 & 2 \\
4. Molecular weight $<500 \mathrm{~g} / \mathrm{mol}$ & 292.10 & 292.10 & 292.10 \\
\hline
\end{tabular}




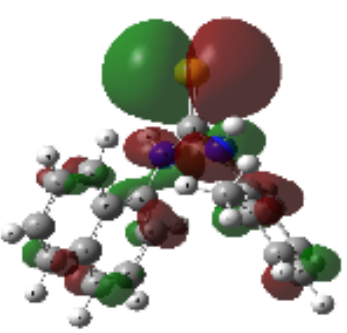

HOMO 3a: $1.3986 \mathrm{Ev}$

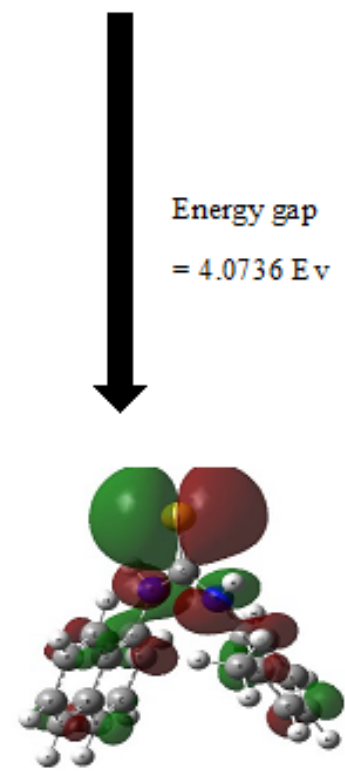

LUMO 3a : $5.4722 \mathrm{Ev}$

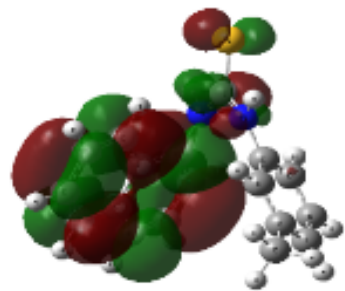

HOMO $3 \mathbf{b}: 1.3823 \mathrm{Ev}$

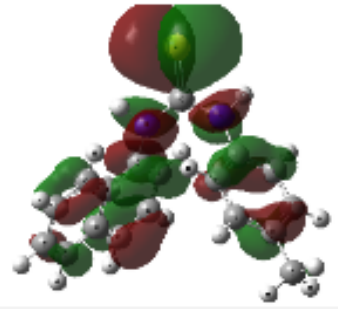

HOMO 3c: $1.4803 \mathrm{Ev}$

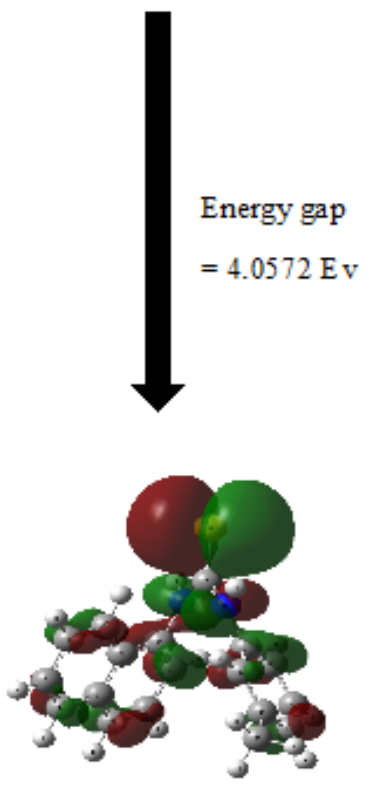

LUMO 3b: $5.4395 \mathrm{Ev}$

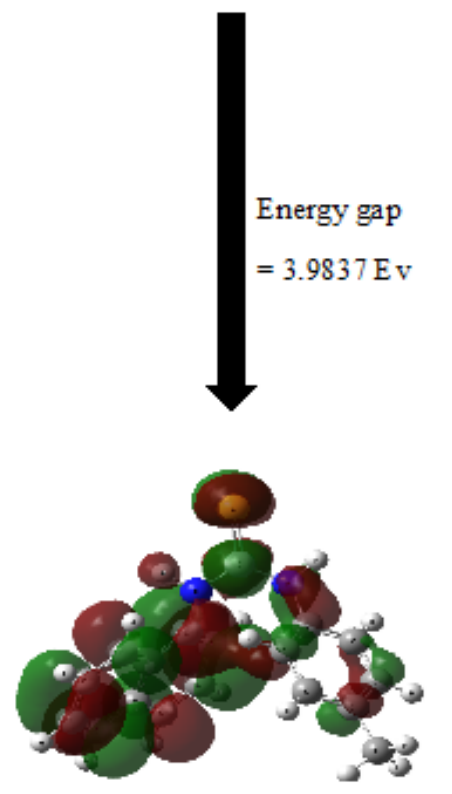

LUMO 3c: $5.4640 \mathrm{Ev}$

FIGURE 2. Frontier molecular orbital for compound 3a-3c

\section{CONCLUSION}

A total of three new thiourea isomers, 1-(naphthalene-1yl)3-(o-tolyl)thiourea 3a, 1-(naphthalene-1-yl)-3-( $m$-tolyl) thiourea $\mathbf{3 b}$ and 1-(naphthalene-1-yl)3-( $p$-tolyl)thiourea $3 \mathbf{c}$ have been successfully synthesized using microwaveirradiation and conventional heating methods. The microwave method showed a high-efficiency reaction $(82-89 \%)$ and a reduces response time compared to the conventional reflux heating method. Antibacterial studies using disc diffusion methods showed that only compound 3c having antibacterial property. DFT computational studies showed that the HOMO-LUMO energy gap for all three compounds has the same values, and these results are proportional to the findings for antibacterial studies.

\section{ACKNOWLEDGEMENTS}

The authors thank the Department of Chemical Sciences, Universiti Kebangsaan Malaysia (UKM), the Centre of
Information and Communication Technology (CICT), Universiti Teknologi Malaysia and the Centre for Research and Instrumentation Management (CRIM), UKM, for providing the facilities. This project is funded by FRGS/1/2018/STG01/UKM/02/14 from the Ministry of Higher Education of Malaysia. The authors also would like to acknowledge Anton Paar Malaysia for giving the opportunity to use their microwave synthesizer Monowave400 for two months.

\section{REFERENCES}

Ardila, N., Daigle, F., Heuzey, M.C. \& Ajji, A. 2017. Antibacterial activity of neat chitosan powder and flakes. Molecules 22(1): 100.

Bardts, M., Gonsior, N. \& Ritter, H. 2008. Polymer synthesis and modification by use of microwaves. Macromolecular Chemistry and Physics 209(1): 25-31.

Caddick, S. \& Fitzmaurice, R. 2009. Microwave enhanced synthesis. Tetrahedron 65(17): 3325-3355. 
Cho, H., Török, F. \& Török, B. 2014. Energy efficiency of heterogeneous catalytic microwave-assisted organic reactions. Green Chemistry 16(7): 3623-3634.

Fakhar, I., Hussien, N.J, Sapari, S., Bloh, A.H., Yusoff, S.F., Hasbullah, S.A., Yamin, B.M., Mutalib, S.A., Shihab, S.M. \& Yousif, E. 2018. Synthesis, X-Ray diffraction, theoretical and anti-bacterial studies of bis-thiourea secondary amine. Journal of Molecular Structure 159: 96-102.

Fakhar, I., Yamin, B.M. \& Hasbullah, S.A. 2016. Synthesis and characterization of bis-thiourea having amino acid derivatives. AIP Conference Proceedings. pp. 030012.

Farzanfar, J., Ghasemi, K., Rezvani, A.R., Delarami, H.S., Ebrahimi, A., Hosseinpoor, H., Eskandari, A., Rudbari, H.A. \& Bruno, G. 2015. Synthesis, characterization, X-ray crystal structure, DFT calculation and antibacterial activities of new vanadium (IV, V) complexes containing chelidamic acid and novel thiourea derivatives. Journal of Inorganic Biochemistry 147: 54-64.

Gangrade, D., Lad, S. \& Mehta, A. 2015. Overview on microwave synthesis-important tool for green chemistry. International Journal of Research in Pharmacy \& Science 5(2): 37-42.

Gao, Y. \& Du, D.M. 2013. Facile synthesis of chiral 2-amino-4(indol-3-yl)-4H-chromene derivatives using thiourea as the catalyst. Tetrahedron: Asymmetry 24(20): 1312-1317.

Halimehjani, A.Z., Pourshojaei, Y. \& Saidi, M.R. 2009. Highly efficient and catalyst-free synthesis of unsymmetrical thioureas under solvent-free conditions. Tetrahedron Letters 50(1): 32-34.

Khansari, M.E., Wallace, K.D. \& Hossain, M.A. 2014. Synthesis and anion recognition studies of a dipodal thiourea-based sensor for anions. Tetrahedron Letters 55(2): 438-440.

Kodomari, M., Suzuki, M., Tanigawa, K. \& Aoyama, T. 2005. A convenient and efficient method for the synthesis of monoand N, N-disubstituted thioureas. Tetrahedron Letters 46(35): 5841-5843.

Larhed, M. \& Hallberg, A. 2001. Microwave-assisted highspeed chemistry: A new technique in drug discovery. Drug Discovery Today 6(8): 406-416.

Liu, W., Zhou, J., Zhang, T., Zhu, H., Qian, H., Zhang, H., Huang, W. \& Gust, R. 2012. Design and synthesis of thiourea derivatives containing a benzo $[5,6]$ cyclohepta $[1,2-b]$ pyridine moiety as potential antitumor and anti-inflammatory agents. Bioorganic \& Medicinal Chemistry Letters 22(8): 2701-2704.

Mallakpour, S. \& Zadehnazari, A. 2012. Simple and efficient microwave-assisted polycondensation for preparation of chiral poly (amide-imide)s having pendant phenol moiety. Polymer Science Series B 54(5-6): 314-322.

Marcos, P.M., Proença, C.S., Teixeira, F.A., Ascenso, J.R., Bernardino, R.J. \& Cragg, P.J. 2013. Synthesis, NMR and DFT conformational studies of homooxacalixarene (cyanopropyl) oxy derivatives, precursors to urea-terminated compounds. Tetrahedron 69(35): 7430-7437.

Misral, H., Sapari, S., Rahman, T., Ibrahim, N., Yamin, B.M. \& Hasbullah, S.A. 2018. Evaluation of novel $\mathrm{N}$-(dibenzylcarbamothioyl) benzamide derivatives as antibacterial agents by using DFT and drug-likeness assessment. Journal of Chemistry 2018: Article ID. 9176280.

Ngah, F.A.A., Zakariah, E.I., Fakhar, I., Hassan, N.I., Heng, L.Y., Yamin, B. \& Hasbullah, S.A. 2018. A new thiourea compound as potential ionophore for metal ion sensor. Indonesian Journal of Chemistry 18(1): 116-120.

Ravichandran, S. \& Karthikeyan, E. 2011. Microwave synthesis-a potential tool for green chemistry. International Journal Chemistry Technology Resources 3(1): 466-470

Sapari, S., Wong, S., Ngatiman, M.F., Misral, H. \& Hasbullah, S.A. 2018. Crystal structure and Hirshfeld analysis of 2-[bis (1-methyl-1H-indol-3-yl) methyl] benzoic acid. Acta Crystallographica Section E: Crystallographic Communications 74(11): 1580-1583.

Sheryn, W., Ngah, F.A.A., Latip, J., Hassan, N.I. \& Hasbullah, S.A. 2018. Solvent-free microwave accelerated synthesis and structural characterization of phthalide-fused indolines. Heterocycles 96(5): 839-849.

Yanai, K., Sumida, N., Okakura, K., Moriya, T., Watanabe, M. \& Murakami, T. 2004. Para-position derivatives of fungal anthelmintic cyclodepsipeptides engineered with Streptomyces Venezuelae antibiotic biosynthetic genes. Nature Biotechnology 22(7): 848-855.

Yang, W., Liu, H., Li, M., Wang, F., Zhou, W. \& Fan, J. 2012. Synthesis, structures and antibacterial activities of benzoylthiourea derivatives and their complexes with cobalt. Journal of Inorganic Biochemistry 116: 97-105.

Yao, J., Chen, J., He, Z., Sun, W. \& Xu, W. 2012. Design, synthesis and biological activities of thiourea containing sorafenib analogs as antitumor agents. Bioorganic \& Medicinal Chemistry 20(9): 2923-2929.

Yin, B., Liu, Z., Yi, M. \& Zhang, J. 2008. An efficient method for the synthesis of disubstituted thioureas via the reaction of N, N'-di-Boc-substituted thiourea with alkyl and aryl amines under mild conditions. Tetrahedron Letters 49(22): 3687-3690.

Yin, X., Chen, J., Yuan, W., Lin, Q., Ji, L. \& Liu, F. 2012. Preparation and antibacterial activity of Schiff bases from O-carboxymethyl chitosan and para-substituted benzaldehydes. Polymer Bulletin 68(5): 1215-1226.

Ying, K.S., Ngah, F.A.A., Sapari, S., Heng, L.Y. \& Hasbullah, S.A. 2019. Complexation study of bis-thiourea compound with aluminium ion as ionophore for development of potentiometric ion sensor. Sains Malaysiana 48(12): 26492661

Zawawi, N.K.N.A., Taha, M., Ahmat, N., Ismail, N.H., Wadood, A., Rahim, F. \& Rehman, A. U. 2015. Synthesis, in vitro evaluation and molecular docking studies of biscoumarin thiourea as a new inhibitor of $\alpha$-glucosidases. Bioorganic Chemistry 63: 36-44.

Zhu, T., He, X. \& Zhang, J.Z. 2012. Fragment density functional theory calculation of NMR chemical shifts for proteins with implicit solvation. Physical Chemistry Chemical Physics 14(21): 7837-7845.

Department of Chemical Sciences

Faculty of Science and Technology

Universiti Kebangsaan Malaysia

43600 UKM Bangi, Selangor Darul Ehsan

Malaysia

*Corresponding author; email: aishah80@ukm.edu.my

Received: 8 June 2020

Accepted: 27 August 2020 